\title{
Extensive Phenotyping for Potential Weight-Inducing Factors in an Outpatient Population with Obesity
}

\author{
Mesut Savas ${ }^{a, b} \quad$ Vincent L. Wester ${ }^{a, b}$ Jenny A. Visser ${ }^{a, b}$ \\ Lotte Kleinendorst $^{d, e}$ Bert van der Zwaag $^{f}$ Mieke M. van Haelst $^{d-f}$ \\ Erica L.T. van den Akker ${ }^{a, c} \quad$ Elisabeth F.C. van Rossum ${ }^{a}, b$ \\ a Obesity Center CGG (Centrum Gezond Gewicht), Erasmus MC, University Medical \\ Center Rotterdam, Rotterdam, The Netherlands; ${ }^{\mathrm{b}}$ Division of Endocrinology, \\ Erasmus MC, University Medical Center Rotterdam, Rotterdam, The Netherlands; \\ 'Pediatric Endocrinology, Erasmus MC, University Medical Center Rotterdam, \\ Rotterdam, The Netherlands; ${ }^{d}$ Clinical Genetics, Amsterdam UMC (AMC), Amsterdam, \\ The Netherlands; ${ }^{e}$ Clinical Genetics, Amsterdam UMC (VUmc), Amsterdam, \\ The Netherlands; ${ }^{\mathrm{f}}$ Genetics, University Medical Center Utrecht, Utrecht, The Netherlands
}

\section{Keywords}

Obesity $\cdot$ Genetics $\cdot$ Secondary causes $\cdot$ Drugs

\section{Abstract}

Background: Obesity has been associated with miscellaneous weight-inducing determinants. A comprehensive assessment of known obesity-related factors other than diet and physical activity within one cohort is currently lacking. Objectives: To assess the prevalence of potential contributors to obesity and self-reported triggers for marked weight gain in an adult population with obesity and between obesity classes. Methods: In this observational cohort study, we assessed 408 persons with obesity (aged $41.3 \pm 14.2$ years, BMl $40.5 \pm 6.2$ ) visiting our obesity clinic. They were evaluated for use of weight-inducing drugs, hormonal abnormalities, menarcheal age, (high) birth weight, sleep deprivation, and obstructive sleep apnea syndrome (OSAS). We additionally assessed self-reported triggers for marked weight gain and performed genetic testing in patients suspected of genetic obesity. Results: Nearly half of the patients were using a potentially weight-inducing drug, which was also the most reported trigger for marked weight gain. For the assessed hormonal conditions, a relatively high prevalence was found for hypothyroidism (14.1\%), polycystic ovary syndrome (12.0\%), and male hypogonadism (41.7\%). A relatively low average menarcheal age (12.6 \pm 1.8 years) was reported, whereas there was a high prevalence of a high birth weight (19.5\%). Sleep deprivation and OSAS were reported in, respectively, 14.5 and $13.7 \%$ of the examined patients. Obesity class appeared to have no influence on the majority of the assessed factors. Of the genetically analyzed patients, a definitive genetic diagnosis was made in 3 patients (1.9\%). Conclusions: 
Savas et al.: Potential Weight-Inducing Factors in Obesity

A thorough evaluation of patients with obesity yields a relatively high prevalence of various potentially weight-inducing factors. Diagnostic screening of patients with obesity could therefore benefit these patients by potentially reducing the social stigma and improving the outcomes of obesity treatment programs by tackling, where possible, the weight-inducing factors in advance.

(C) 2019 The Author(s)

Published by S. Karger AG, Basel

\section{Introduction}

In the last decades, there has been an evident increase worldwide in the prevalence of obesity [1]. This ominous trend brings along many health problems given the strong associations between adiposity and noncommunicable diseases. In addition to metabolic and cardiovascular diseases, obesity carries an increased risk of various cancer types, depression, and other illnesses compromising the quality of life.

The multifactorial etiology of obesity makes it difficult to find a long-lasting solution. Dietary composition and reduced physical activity, also acclaimed as the "big two" by Keith et al. [2], have always been of major concern regarding the epidemic and treatment of obesity. However, this approach tends to undervalue other factors also described to contribute to or at least maintain obesity. For instance, various genetic alterations have been found to induce obvious monogenic (e.g., melanocortin 4 receptor $[M C 4 R]$ and proopiomelanocortin $[P O M C]$ mutations) or syndromic forms of obesity (e.g., Prader-Willi and Bardet-Biedl syndromes) or have been linked to nonsyndromic obesity in which the onset and severity depend on interaction with the environment. Other relatively more prevalent factors that increase the risk of obesity are, for example, an early age at menarche, [3] a high birth weight, [4,5] and various hormonal causes such as hypothyroidism, (endogenous or exogenous) Cushing's syndrome, and hypothalamic abnormalities [6]. Additionally, there are also diverse potentially modifiable weight-inducing factors such as the use of obesogenic drugs [7], and diminished sleep duration [8, 9], or factors for which the direction of association has not yet been fully understood or is bidirectional (e.g., low testosterone levels [10], polycystic ovary syndrome [PCOS] [11], and obstructive sleep apnea syndrome [OSAS] [12]).

Most experimental and observational studies regarding obesity usually highlight one particular factor. One of the targets of our multidisciplinary referral center for obesity is to systematically evaluate and identify those factors that could induce and/or maintain excess body weight in adults. Hence, the main purpose of this study was to extensively phenotype and assess multiple potential weight-inducing factors, as mentioned above, within our total obese cohort and stratified by adult obesity classes. Our secondary objectives were to evaluate the relationship with self-reported triggers for marked weight gain and to assess the yield of targeted genetic screening for obesity.

\section{Participants and Methods}

\section{Study Population}

Patients with obesity were referred to our academic obesity center CGG for assessment of potential contributing factors to adiposity. After registration, a comprehensive standardized medical questionnaire was sent to the patients for a more thorough evaluation of, among other things, their medical history, drug use, family history, and other factors as assessed here. We assessed data of patients who were seen at the outpatient clinic between 
June 2011 and August 2016. After excluding individuals who had a BMI below 30.0 at the time of the clinic visit or insufficient data, a total of 408 patients with obesity were included in the current study.

\section{Sociodemographic Factors}

Weight, height, and blood pressure were measured during the site visit. BMI was computed by dividing weight $(\mathrm{kg})$ by height $\left(\mathrm{m}^{2}\right)$. Nationality was determined according to Statistics Netherlands [13]. The highest attendant education level was coded as follows: low (i.e., no education, primary education, or special education), middle (i.e., secondary education or vocational studies), or high (i.e., higher professional education or university education).

\section{Assessment of Potential Weight-Inducing Factors}

Medical history and drug use were assessed using the referral letter of the primary care provider and completed medical questionnaires and were subsequently confirmed and further detailed during the outpatient clinic visit.

Currently used drugs were assessed for potential weight-inducing adverse events. Accordingly, we compiled a list of drugs which were previously reported to be associated with weight gain (Table 1) [7,14-21]. For exploratory purposes, we additionally included drugs which were less frequently been reported as weight-inducing (e.g., antihistamines and proton pump inhibitors) as compared to the well-established obesogenic drugs. Hormonal contraceptives, other than medroxyprogesterone, were not included due to the controversy about their weight-altering effects [22].

Thyroid function was categorized into the following 4 groups based on the availability of both medical history and current thyroid function measurements: (1) euthyroid (i.e., no history of a thyroid disorder and normal thyroid function tests), (2) hypothyroidism (including all patients who were previously or newly diagnosed with hypothyroidism and patients who underwent thyroidectomy; these patients were subdivided into groups of patients who were currently inadequately treated [increased thyroid-stimulating hormone (TSH) levels], patients who were adequately treated or had a resolved hypothyroidism [normal TSH and free thyroxine (FT4) levels], patients who were overtreated [lowered TSH levels], and patients with other thyroid function test results), (3) subclinical hypothyroidism, and (4) other thyroid states. For this, blood samples were drawn for determination of, among other things, TSH and FT4 as part of our routine lab measurements.

PCOS was classified as previously diagnosed if the patient indicated having been investigated earlier and the diagnosis was established. For screening purposes, patients suspected to have PCOS were referred to a specialized gynecological outpatient clinic. Clinically suspected patients who were not (yet) further investigated or for whom the results were still pending due to investigations elsewhere were classified as a separate category.

In male patients without testosterone replacement therapy, total testosterone and sex hormone-binding globulin (SHBG) were measured if necessary to determine male hypogonadism. Due to the association of SHBG with body weight, we calculated non-SHBG-bound testosterone according to de Ronde et al. [23]. Male hypogonadism was defined as non-SHBG testosterone levels lower than 2 SD from the mean according to the corresponding age category as noted by de Ronde et al. [23], with patients younger than 40 years belonging to the youngest category.

Subjects were also evaluated for age at menarche (years), self-reported birth weight (g), and average sleep duration (h/night). With respect to OSAS, we referred suspected cases to an otolaryngologist and classified the patients using the same format as for PCOS. 
Table 1. Overview of drugs described to be associated with weight gain $[7,14-21]$
Savas et al.: Potential Weight-Inducing Factors in Obesity

\begin{tabular}{|c|c|c|}
\hline Drug class & Drug name & \\
\hline Anticonvulsants & $\begin{array}{l}\text { Carbamazepine } \\
\text { Gabapentin } \\
\text { Pregabalin } \\
\text { Valproic acid }\end{array}$ & \\
\hline Antidepressants & $\begin{array}{l}\text { Amitriptyline } \\
\text { Citalopram } \\
\text { Clomipramine } \\
\text { Clovoxamine } \\
\text { Desipramine } \\
\text { Doxepin } \\
\text { Duloxetine } \\
\text { Escitalopram } \\
\text { Fluoxetine } \\
\text { Fluvoxamine }\end{array}$ & $\begin{array}{l}\text { Imipramine } \\
\text { Maprotiline } \\
\text { Mirtazapine } \\
\text { Nortriptyline } \\
\text { Paroxetine } \\
\text { Phenelzine } \\
\text { Sertraline } \\
\text { Tranylcypromine } \\
\text { Trimipramine }\end{array}$ \\
\hline Antihistamines & $\begin{array}{l}\text { Astemizole } \\
\text { Cetirizine } \\
\text { Cyproheptadine }\end{array}$ & $\begin{array}{l}\text { Diphenhydramine } \\
\text { Fexofenadine } \\
\text { (Des)loratadine }\end{array}$ \\
\hline Antipsychotics & $\begin{array}{l}\text { Aripiprazole } \\
\text { Chlorpromazine } \\
\text { Clozapine } \\
\text { Fluphenazine } \\
\text { Haloperidol } \\
\text { Lithium } \\
\text { Olanzapine } \\
\text { Paliperidone }\end{array}$ & $\begin{array}{l}\text { Perphenazine } \\
\text { Quetiapine } \\
\text { Risperidone } \\
\text { Thioridazine } \\
\text { Thiothixene } \\
\text { Trifluoperazine } \\
\text { (Ziprasidone) }^{\mathrm{a}}\end{array}$ \\
\hline \multicolumn{3}{|l|}{ Corticosteroids } \\
\hline Diabetes drugs & $\begin{array}{l}\text { Insulin } \\
\text { Sulfonylurea } \\
\text { Chlorpropamide } \\
\text { Glibenclamide } \\
\text { Glimepiride } \\
\text { Glipizide }\end{array}$ & $\begin{array}{c}\text { Thiazolidinediones } \\
\text { Troglitazone } \\
\text { Pioglitazone } \\
\text { Rosiglitazone }\end{array}$ \\
\hline $\begin{array}{l}\text { Hypertension } \\
\text { drugs }\end{array}$ & $\begin{array}{l}\alpha \text {-Blockers } \\
\quad \text { Clonidine } \\
\quad \text { Prazosin } \\
\text { Terazosin } \\
\beta \text {-Blockers } \\
\text { Atenolol } \\
\quad \text { Metoprolol } \\
\text { Propranolol }\end{array}$ & $\begin{array}{l}\text { Calcium channel } \\
\text { blockers } \\
\text { Flunarizine } \\
\text { Nisoldipine } \\
\text { Centrally acting agents } \\
\text { Methyldopa }\end{array}$ \\
\hline $\begin{array}{r}\text { Proton pump } \\
\text { inhibitors }\end{array}$ & $\begin{array}{l}\text { Lansoprazole } \\
\text { Omeprazole } \\
\text { Rabeprazole }\end{array}$ & \\
\hline Others & $\begin{array}{l}\text { Leuprolide acetate } \\
\text { Medroxyprogesterone } \\
\text { Pizotifen } \\
\text { Protease inhibitor }\end{array}$ & \\
\hline
\end{tabular}

${ }^{\text {a }}$ Reported to induce both weight gain [7] and weight loss [15]; current use of ziprasidone was not observed in our sample. ${ }^{b}$ Also known as glyburide in the USA. 
Savas et al.: Potential Weight-Inducing Factors in Obesity

Table 2. Gene panel for syndromic and nonsyndromic obesity analysis

\begin{tabular}{|c|c|c|c|c|c|}
\hline \multicolumn{6}{|c|}{ Gene name } \\
\hline$A L M S 1$ & $B D N F$ & KIDINS220 & $M K S 1$ & PTEN & $T U B$ \\
\hline$A R L 6$ & $C C D C 28 B$ & $L E P$ & $M R A P 2$ & SIM1 & WDPCP \\
\hline$B B S 1$ & СЕР290 & $L E P R$ & $N D N$ & SNRPD2 & \\
\hline$B B S 2$ & CRHR2 & LZTFL1 & NTRK2 & SNRPN & \\
\hline$B B S 4$ & FLOT1 & MAGEL2 & PAX6 & SPG11 & \\
\hline BBS5 & $G 6 P C$ & $M C 3 R$ & $P C K 1$ & TBX3 & \\
\hline$B B S 7$ & GNAS & $M C 4 R$ & PCSK1 & THRB & \\
\hline$B B S 9$ & $\operatorname{IRS} 1^{\mathrm{a}}$ & MCHR1 & PHF6 & TMEM67 & \\
\hline BBS10 & $I R S 2^{\mathrm{a}}$ & $M K K S$ & POMC & TRIM32 & \\
\hline BBS12 & $I R S 4^{\mathrm{a}}$ & $M K R N 3$ & PRKAR1A & ТTC8 & \\
\hline
\end{tabular}

a These genes were analyzed for the purpose of evaluating comorbidity risk (type 2 diabetes mellitus).

\section{Assessment of Marked Weight Gain}

In order to also evaluate subjective reasons for weight gain, we assessed self-reported data about potential causes of any previous period of marked weight gain. For this purpose, we assessed reasons other than unhealthy eating behaviors and/or physical inactivity and categorized these as related to: health, psychosocial stress, work, pregnancy, drug use, substance cessation, and other causes.

\section{Genetic Analysis}

A genetic test was performed in a selection of 162 patients $(39.7 \%)$. They fulfilled the criteria for requesting this analysis based on clinical suspicion of syndromic obesity (e.g., early-onset obesity with dysmorphic features/congenital malformations with or without an intellectual deficit, behavior problems, hyperphagia, and/or a striking family history), had intractable obesity despite a healthy lifestyle and repeated weight-loss attempts without other potential secondary causes, or had an insufficient response or a non-response to our intensive combined lifestyle treatment programs. Targeted diagnostic DNA sequencing of 52 obesity-related genes, including 3 genes related to type 2 diabetes mellitus (Table 2), covering protein coding exons and flanking splice site consensus sequences, was performed at the IS015189 accredited genome diagnostics department of UMC Utrecht. DNA was enriched using an Agilent SureSelectXT custom enrichment assay (ELID\#0561501) followed by nextgeneration sequencing on an Applied Biosystems 5500XL SOLiD sequencer at a minimum of $100 \times$ median coverage. Horizontal coverage of the targeted sequence at $>15 \times$ was $>95 \%$. The poorly captured fourth exon of the POMC gene (transcript NM_001035256.1) was analyzed via the Sanger sequencing method to reach $>99 \%$ coverage for this gene (primer sequences are available on request).

\section{Statistical Analysis}

IBM SPPS Statistics version 21 (IBM Corp., Armonk, NY, USA) was used for statistical analyses. Age at menarche was assessed continuously. For exploratory purposes, we also evaluated the prevalence of precocious menarche (i.e., younger than 9 years). Sleep duration and birth weight were assessed both as continuous and as categorical variables (i.e., <6.0, $6.0-8.0$, and $\geq 8.0 \mathrm{~h} /$ night for sleep duration; $<4,000 \mathrm{~g}$ and $\geq 4,000 \mathrm{~g}$ [i.e., high birth weight] for birth weight). In order to compare the differences in outcomes by severity of obesity, we analyzed our cohort using the following $3 \mathrm{BMI}$ classes according to the WHO classification of adult obesity [24]: class I obesity for BMI between 30.00 and 34.99, class II for BMI between 35.00 and 39.99 , and class III for BMI $\geq 40.00$. Crude between-group differences in categorical 
Table 3. Descriptive characteristics of the study sample

\begin{tabular}{|c|c|c|c|c|c|}
\hline & \multirow{2}{*}{$\begin{array}{l}\text { Subjects, } \\
n\end{array}$} & \multirow[t]{2}{*}{ Overall } & \multicolumn{3}{|l|}{ Adult obesity class ${ }^{\mathrm{a}}$} \\
\hline & & & $\begin{array}{l}\mathrm{I} \\
(n=69)\end{array}$ & $\begin{array}{l}\text { II } \\
(n=144)\end{array}$ & $\begin{array}{l}\text { III } \\
(n=195)\end{array}$ \\
\hline Age, years & 408 & $41.3 \pm 14.2$ & $39.8 \pm 14.5$ & $41.0 \pm 13.7$ & $42.1 \pm 14.5$ \\
\hline Female sex & 408 & $308(76)$ & $48(70)$ & $109(76)$ & $151(77)$ \\
\hline BMI & 408 & $40.5 \pm 6.2$ & $33.1 \pm 1.4$ & $37.5 \pm 1.5$ & $45.4( \pm 5.2)$ \\
\hline Blood pressure, mm Hg & 396 & & & & \\
\hline Systolic & & $140 \pm 18$ & $137 \pm 16$ & $138 \pm 16$ & $142 \pm 19$ \\
\hline Diastolic & & $81 \pm 13$ & $79 \pm 13$ & $82 \pm 12$ & $82 \pm 13$ \\
\hline Nationality & 408 & & & & \\
\hline Native & & $295(72.3)$ & $49(71.0)$ & $111(77.1)$ & $135(69.2)$ \\
\hline Western background & & $24(5.9)$ & $3(4.3)$ & $11(7.6)$ & $10(5.1)$ \\
\hline Non-Western background & & $89(21.8)$ & $17(24.6)$ & $22(15.3)$ & $50(25.6)$ \\
\hline Education level & 361 & & & & \\
\hline Low & & $20(5.5)$ & $2(3.5)$ & $6(4.7)$ & $12(6.9)$ \\
\hline Middle & & $197(54.6)$ & $26(45.6)$ & $69(53.5)$ & $102(58.3)$ \\
\hline High & & $144(39.9)$ & $29(50.9)$ & $54(41.9)$ & $61(34.9)$ \\
\hline Menarcheal age, years & 301 & $12.0(11.0-15.0)$ & $12.0(10.9-15.1)$ & $12.5(11.0-14.0)$ & $12.0(11.0-15.0)$ \\
\hline Sleeping, h/night & 311 & $7.1 \pm 1.4$ & $7.1 \pm 1.4$ & $7.1 \pm 1.3$ & $7.1 \pm 1.4$ \\
\hline$<6.0$ & & $45(14.5)$ & $8(17.0)$ & $18(16.2)$ & $19(12.4)$ \\
\hline $6.0-8.0$ & & $170(54.7)$ & $22(46.8)$ & $59(53.2)$ & $89(58.2)$ \\
\hline$\geq 8.0$ & & $96(30.9)$ & $17(36.2)$ & $34(30.6)$ & $45(29.4)$ \\
\hline Birth weight, g & 272 & $3,402 \pm 744$ & $3,423 \pm 698$ & $3,361 \pm 805$ & $3,428 \pm 711$ \\
\hline$<4,000$ & & $219(80.5)$ & $37(80.4)$ & 87 (83.7) & 95 (77.9) \\
\hline$\geq 4,000$ & & $53(19.5)$ & 9 (19.6) & $17(16.3)$ & $27(22.1)$ \\
\hline
\end{tabular}

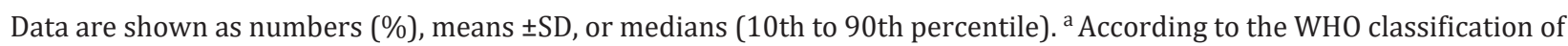
adult obesity [24], i.e., class I, BMI between 30.00 and 34.99; class II, BMI between 35.00 and 39.99; and class III, BMI equal to or greater than 40.00 .

variables were tested using a $\chi^{2}$ test or Fisher's exact test, and for continuous variables ANOVA or the Kruskal-Wallis test was used when appropriate. The Mantel-Haenszel test for trend was performed to assess trends in prevalence numbers across the obesity classes. Logistic regression models and ANCOVA were used for between-group analyses with adjustments for sex and/or age as indicated. For all tests, $p<0.05$ was considered statistically significant.

\section{Results}

\section{Sample Characteristics}

The general characteristics for the entire group and stratified by the 3 classes of adult obesity are provided in Table 3. About half of our cohort was classified as having class III obesity. No differences were found between classes with regard to sociodemographic factors.

\section{Potentially Weight-Inducing Factors}

Overall, $48.0 \%$ of the patients were using any potentially weight-inducing drug at the time of the clinic visit. Corticosteroids (local and systemic) were the most used weightinducing drugs (23.8\%), followed by proton pump inhibitors (11.3\%), antihistamines $(8.6 \%)$, 


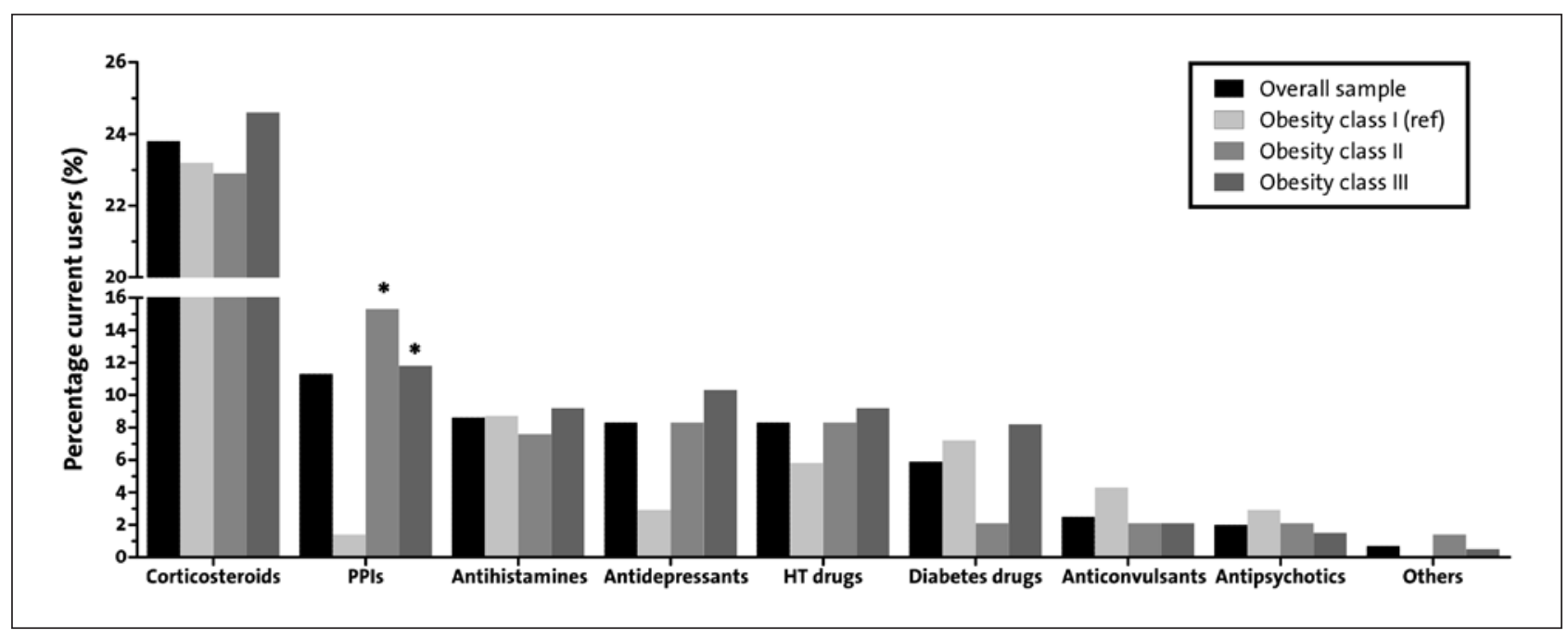

Fig. 1. Current use of potentially weight-inducing drugs (Table 1) by subjects with obesity in the overall group and stratified by obesity class (i.e., class I, BMI = 30.00-34.99; class II, BMI = 35.00-39.99; and class III, BMI $\geq 40.00$ ). Between-group analyses, with class I as the reference group, were performed with logistic regression analyses with adjustments for sex and age. ${ }^{*} p<0.05$. HT, hypertension; PPI, proton pump inhibitor; ref, reference.

antidepressants (8.3\%), hypertension drugs (8.3\%), diabetes drugs (5.9\%), anticonvulsants $(2.5 \%)$, antipsychotics $(2.0 \%)$, and other drugs $(0.7 \%)$ such as medroxyprogesterone $(0.5 \%)$ and protease inhibitors $(0.2 \%)$. Except for proton pump inhibitors, the 3 obesity classes did not differ in use of any of the potentially weight-inducing drugs (Fig. 1).

The majority of the patients had no history of any thyroid disorder in combination with normal thyroid hormone test results (Table 4 ). Five hypothyroid patients $(10.0 \%$ of the hypothyroid group) were undertreated with thyroxine analogs. A new diagnosis of hypothyroidism and subclinical hypothyroidism was made in, respectively, $2(0.6 \%)$ and $9(2.5 \%)$ of the screened cases. No significant differences were noted in prevalence rates of (subclinical) hypothyroidism between the 3 obesity classes.

Thirty female patients $(9.7 \%)$ presented with PCOS at the first visit. After consultation, 17 (5.5\%) women were additionally suspected of having PCOS. The diagnosis could be confirmed in 7 women, yielding a prevalence rate of PCOS in our female obese sample of at least $12.0 \%$ given the fact that some were evaluated elsewhere or decided not to undergo any further investigation at that moment (Fig. 2a). A higher obesity class was associated with a lower PCOS prevalence rate $(20.8,14.7$, and $7.3 \%$ from the lowest to the highest class), but this did not reach statistical significance after adjustment for age.

Thirty-six male patients, aged $44.0 \pm 14.7$ years, had their total testosterone and SHBG levels measured. Non-SHBG-bound testosterone levels showed an incremental decrease across the obesity classes ( $p=0.035$, adjusted for age). Hypogonadism was present in $41.7 \%$ of the investigated men, with prevalences ranging from $20.0(1 / 5)$ to $47.1(8 / 17)$ and $42.9 \%$ $(6 / 14)$ in the consecutive classes. No novel cases in endogenous Cushing's syndrome or growth hormone deficiency were diagnosed. Obesity due to iatrogenic damage to the pituitary and/or the hypothalamus was suspected in 2 patients; one of whom had developed hyperphagia after excision of suprasellar craniopharyngioma and the other of whom gained substantial weight after undergoing surgery with adjuvant radiotherapy for a nonfunctioning pituitary macroadenoma. 
Table 4. Thyroid status in outpatients with obesity

\begin{tabular}{|c|c|c|c|c|}
\hline & \multirow{2}{*}{$\begin{array}{l}\text { Overall } \\
(n=354)\end{array}$} & \multicolumn{3}{|c|}{ Adult obesity class ${ }^{\mathrm{a}}$} \\
\hline & & $\begin{array}{l}\mathrm{I} \\
(n=60)\end{array}$ & $\begin{array}{l}\text { II } \\
(n=122)\end{array}$ & $\begin{array}{l}\text { III } \\
(n=172)\end{array}$ \\
\hline Euthyroid & $280(79.1)$ & $43(71.7)$ & $100(82.0)$ & 137 (79.7) \\
\hline Hypothyroidism & $50(14.1)$ & $13(21.7)$ & $12(9.8)$ & $25(14.5)$ \\
\hline Adequately treated or resolved & $31(8.8)$ & $8(13.3)$ & $6(4.9)$ & $17(9.9)$ \\
\hline Inadequately treated & $5(1.4)$ & $1(1.7)$ & $2(1.6)$ & $2(1.2)$ \\
\hline Overtreated & $10(2.8)$ & $4(6.7)$ & $3(2.5)$ & $3(1.7)$ \\
\hline Undiagnosed & $2(0.6)$ & $0(0.0)$ & $1(0.8)$ & $1(0.6)$ \\
\hline Others ${ }^{b}$ & $2(0.6)$ & $0(0.0)$ & $0(0.0)$ & $2(1.2)$ \\
\hline Subclinical hypothyroidism & $15(4.2)$ & $1(1.7)$ & $7(5.7)$ & 7 (4.1) \\
\hline Previously diagnosed & $6(1.7)$ & $1(1.7)$ & $3(2.5)$ & $2(1.2)$ \\
\hline Undiagnosed & $9(2.5)$ & $0(0.0)$ & $4(3.3)$ & $5(2.9)$ \\
\hline Others $^{c}$ & $9(2.5)$ & $3(5.0)$ & $3(2.5)$ & $3(1.7)$ \\
\hline
\end{tabular}

Data are shown as numbers (\%). ${ }^{\text {a }}$ According to the WHO classification of adult obesity [24], i.e., class I, BMI between 30.00 and 34.99; class II, BMI between 35.00 and 39.99; and class III, BMI equal to or greater than $40.00 .{ }^{\mathrm{b}}$ Includes 1 patient with hypothyroidism during block and replace therapy for Graves disease and 1 patient with untreated hypothyroidism in history with recent altered thyroid hormone tests suspected of amiodarone-induced thyrotoxicosis. ${ }^{c}$ Includes 9 patients with no known thyroid disorder in the past but laboratory tests showed subclinical hyperthyroidism $(n=2)$, normal TSH levels with decreased FT4 values $(n=6)$, and normal TSH levels with increased FT4 levels $(n=1)$.

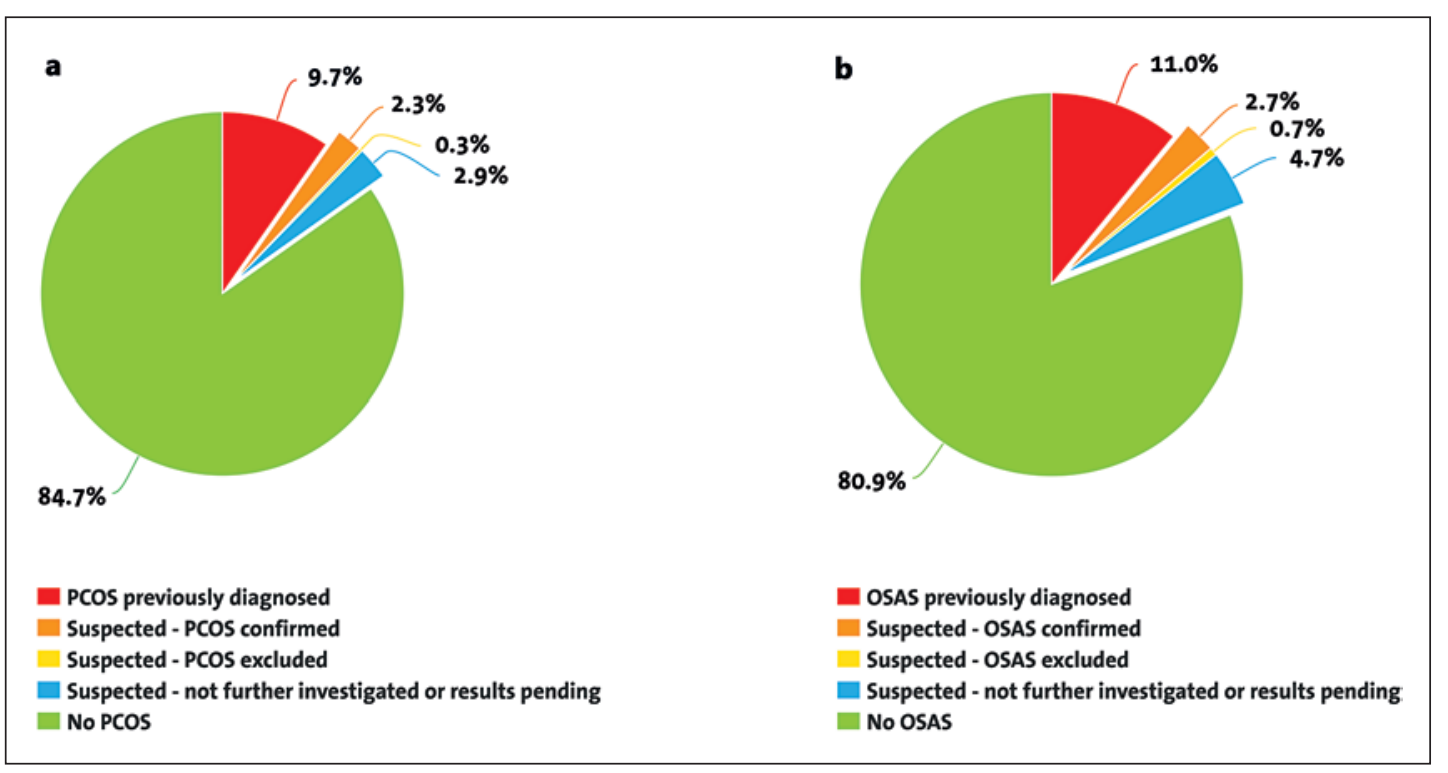

Fig. 2. Prevalence rates of PCOS (a) and OSAS (b) in subjects with obesity. The pulled slices represent the status of adult subjects with obesity suspected of having PCOS or OSAS after the clinic visit.

The age at menarche was on average $12.6 \pm 1.8$ years with a median (10th to 90th percentile) of 12.0 (11.0-15.0) years (Table 3). Precocious menarche was present in 2 women with class III adult obesity. No significant differences were found between the classes and there were no differences by nationality. 
Table 5. Genetic screening results for obesity-related genes in our population of subjects with obesity

\begin{tabular}{llllll}
\hline No. Gene & $\begin{array}{l}\text { Genetic } \\
\text { defect }\end{array}$ & Sex & Class $^{\mathrm{a}}$ & Variation & Explanation \\
\hline \multicolumn{7}{l}{\begin{tabular}{l} 
Definitive diagnosis of genetic obesity \\
\hline 1
\end{tabular} MC4R } & Pathogenic & F & III & $\begin{array}{l}\text { Heterozygous c.105C }>\mathrm{A}, \\
\text { p.(Tyr35*) }\end{array}$ \\
\hline 2 & MC4R & Pathogenic & F & III & $\begin{array}{l}\text { Heterozygous c.105C }>\mathrm{A}, \\
\text { p.(Tyr35*) }\end{array}$ \\
\hline 3 & POMC & Pathogenic & F & III & $\begin{array}{l}\text { Heterozygous c.662A }>\mathrm{G}, \\
\text { p.(Tyr221Cys) }\end{array}$ \\
\hline
\end{tabular}

Possible diagnosis of genetic obesity or risk factor for obesity

\begin{tabular}{llll}
\hline 4 LEPR VUS & F II $\quad \begin{array}{l}\text { Heterozygous c.1835G }>\mathrm{A}, \\
\text { p.(Arg612His) }\end{array}$
\end{tabular}

Pathogenic heterozygous LEPR mutations are a known risk factor for obesity; segregation analysis needed; this mutation is described in patients with a leptin receptor deficiency in combination with other pathogenic LEPR mutations

\begin{tabular}{|c|c|c|c|c|c|c|}
\hline 5 & $L E P R$ & VUS & $\mathrm{F}$ & III & $\begin{array}{l}\text { Heterozygous c. } 2963 \mathrm{C}>\mathrm{T} \text {, } \\
\text { p.(Thr988Met) }\end{array}$ & $\begin{array}{l}\text { Pathogenic heterozygous } L E P R \text { muta- } \\
\text { tions are a known risk factor for obesity; } \\
\text { segregation analysis needed }\end{array}$ \\
\hline 6 & $\begin{array}{l}\text { MRAP2 } \\
\text { CEP290 }\end{array}$ & $\begin{array}{l}\text { Likely patho- } \\
\text { genic } \\
\text { Pathogenic }\end{array}$ & $\mathrm{F}$ & II & $\begin{array}{l}\text { Heterozygous c.373C }>\mathrm{T} \text {, } \\
\text { p.(Arg125Cys) } \\
\text { Heterozygous c.4723A>T, } \\
\text { p.(Lys1575*) }\end{array}$ & $\begin{array}{l}\text { MRAP2 is likely a pathogenic variant; } \\
\text { segregation analysis needed; CEP290 } \\
\text { carrier status autosomal recessive } \\
\text { disease; probably no or a low-risk factor } \\
\text { for obesity }\end{array}$ \\
\hline 7 & MRAP2 & $\begin{array}{l}\text { Likely patho- } \\
\text { genic }\end{array}$ & $\mathrm{F}$ & III & $\begin{array}{l}\text { Heterozygous c.373C >T, } \\
\text { p.(Arg125Cys) }\end{array}$ & $\begin{array}{l}\text { Likely a pathogenic variant; segregation } \\
\text { analysis needed }\end{array}$ \\
\hline 8 & $M R A P 2$ & $\begin{array}{l}\text { Likely patho- } \\
\text { genic }\end{array}$ & $\mathrm{F}$ & III & $\begin{array}{l}\text { Heterozygous c. } 520 \mathrm{C}>\mathrm{T} \text {, } \\
\text { p. }\left(\mathrm{G} \ln 174^{*}\right)\end{array}$ & Likely a pathogenic variant \\
\hline 9 & $\begin{array}{l}\text { PCK1 } \\
\text { PCK1 }\end{array}$ & $\begin{array}{l}\text { VUS } \\
\text { VUS }\end{array}$ & M & III & $\begin{array}{l}\text { Heterozygous c.1397C>T, } \\
\text { p.(Ala466Val) } \\
\text { Heterozygous c.1628G>A, } \\
\text { p.(Arg543Gln) }\end{array}$ & $\begin{array}{l}\text { Segregation analysis showed that a } \\
\text { skinny sib did not have any of the } \\
\text { variants }\end{array}$ \\
\hline 10 & POMC & VUS & M & III & $\begin{array}{l}\text { Heterozygous c.229T>G, } \\
\text { p.(Tyr77Asp) }\end{array}$ & $\begin{array}{l}\text { Pathogenic heterozygous } P O M C \text { muta- } \\
\text { tions are a known risk factor for obesity; } \\
\text { segregation analysis identified the } \\
\text { mutation in an obese brother, which } \\
\text { makes pathogenicity more likely }\end{array}$ \\
\hline 11 & SNRPN & $\begin{array}{l}\text { Likely patho- } \\
\text { genic }\end{array}$ & $\mathrm{F}$ & I & $\begin{array}{l}\text { Heterozygous c. } 193 \mathrm{C}>\mathrm{T} \text {, } \\
\text { p.(Arg65Trp) }\end{array}$ & $\begin{array}{l}\text { Likely pathogenic variant fitting with the } \\
\text { phenotype, but first described missense } \\
\text { mutations, further segregation analysis } \\
\text { and/or functional study is needed }\end{array}$ \\
\hline 12 & TBX3 & VUS & $\mathrm{F}$ & III & $\begin{array}{l}\text { Heterozygous c. } 2177 \mathrm{G}>\mathrm{T} \text {, } \\
\text { p.(Arg726Leu) }\end{array}$ & $\begin{array}{l}\text { Autosomal dominant diseases, segre- } \\
\text { gation analysis not yet performed }\end{array}$ \\
\hline \multicolumn{7}{|c|}{ No genetic explanation for obesity (yet): VUS or noninterpretable status } \\
\hline 13 & $B B S 1$ & Pathogenic & $\mathrm{F}$ & I & $\begin{array}{l}\text { Heterozygous c.1570_1572del, } \\
\text { p.(Asn524del) }\end{array}$ & $\begin{array}{l}\text { Carrier status autosomal recessive } \\
\text { disease; probably no or low-risk factor } \\
\text { for obesity }\end{array}$ \\
\hline
\end{tabular}


Table 5 (continued)

\begin{tabular}{|c|c|c|c|c|c|c|}
\hline No. & Gene & $\begin{array}{l}\text { Genetic } \\
\text { defect }\end{array}$ & Sex & Class $^{\mathrm{a}}$ & Variation & Explanation \\
\hline 14 & $B B S 1$ & VUS & $\mathrm{F}$ & II & $\begin{array}{l}\text { Heterozygous c. } 742 \mathrm{C}>\mathrm{A} \text {, } \\
\text { p.(Pro248Thr) }\end{array}$ & $\begin{array}{l}\text { Carrier status autosomal recessive } \\
\text { disease; probably no or low-risk factor } \\
\text { for obesity }\end{array}$ \\
\hline 15 & $B B S 4$ & VUS & $\mathrm{M}$ & II & $\begin{array}{l}\text { Heterozygous c. } 137 \mathrm{~A}>\mathrm{G} \text {, } \\
\text { p.(Lys46Arg) }\end{array}$ & $\begin{array}{l}\text { Carrier status autosomal recessive } \\
\text { disease; probably no or low-risk factor } \\
\text { for obesity }\end{array}$ \\
\hline 16 & BBS5 & VUS & M & III & $\begin{array}{l}\text { Heterozygous c.110T>C, } \\
\text { p.(Ile37Thr) }\end{array}$ & $\begin{array}{l}\text { Carrier status autosomal recessive } \\
\text { disease; probably no or low-risk factor } \\
\text { for obesity }\end{array}$ \\
\hline 17 & $B B S 9$ & VUS & $\mathrm{F}$ & III & $\begin{array}{l}\text { Heterozygous c. } 1600 \mathrm{~A}>\mathrm{G} \text {, } \\
\text { p.(Ile534Val) }\end{array}$ & $\begin{array}{l}\text { Carrier status autosomal recessive } \\
\text { disease; probably no or low-risk factor } \\
\text { for obesity }\end{array}$ \\
\hline 18 & BBS12 & VUS & M & III & $\begin{array}{l}\text { Heterozygous c. } 1367 \mathrm{~A}>\mathrm{G} \text {, } \\
\text { p.(Tyr456Cys) }\end{array}$ & $\begin{array}{l}\text { Carrier status autosomal recessive } \\
\text { disease; probably no or low-risk factor } \\
\text { for obesity }\end{array}$ \\
\hline 19 & BBS12 & Pathogenic & M & III & $\begin{array}{l}\text { Heterozygous c.476C >T, } \\
\text { p.(Pro159Leu) }\end{array}$ & $\begin{array}{l}\text { Carrier status autosomal recessive } \\
\text { disease; probably no or low-risk factor } \\
\text { for obesity }\end{array}$ \\
\hline 20 & CEP290 & $\begin{array}{l}\text { Pathogenic } \\
\text { VUS }\end{array}$ & $\mathrm{F}$ & II & $\begin{array}{l}\text { Heterozygous c.6516del, } \\
\text { p.(Lys2172fs) } \\
\text { Heterozygous c.564T>G, } \\
\text { p.(Asp188Glu) }\end{array}$ & $\begin{array}{l}\text { No clinical features of Bardet-Biedl } \\
\text { syndrome; probably no or low-risk } \\
\text { factor for obesity }\end{array}$ \\
\hline 21 & CEP290 & $\begin{array}{l}\text { VUS } \\
\text { VUS }\end{array}$ & $\mathrm{F}$ & III & $\begin{array}{l}\text { Heterozygous c.7190T>C, } \\
\text { p.(Leu2397Pro) } \\
\text { Heterozygous c.7394_7395del, } \\
\text { p.(Glu2465fs) }\end{array}$ & $\begin{array}{l}\text { Carrier status autosomal recessive } \\
\text { disease; probably no or low-risk factor } \\
\text { for obesity; variants in cis }\end{array}$ \\
\hline 22 & PCK1 & VUS & $\mathrm{F}$ & III & $\begin{array}{l}\text { Heterozygous c.1526C }>\mathrm{T} \text {, } \\
\text { p.(Pro509Leu) }\end{array}$ & $\begin{array}{l}\text { Carrier status autosomal recessive } \\
\text { disease; no known dominant phenotype }\end{array}$ \\
\hline 23 & SPG11 & VUS & $\mathrm{F}$ & III & $\begin{array}{l}\text { Heterozygous c. } 5121 \mathrm{G}>\mathrm{T} \text {, } \\
\text { p.(Glu1707Asp) }\end{array}$ & $\begin{array}{l}\text { Carrier status autosomal recessive } \\
\text { disease; no known dominant phenotype }\end{array}$ \\
\hline 24 & SPG11 & Pathogenic & $\mathrm{F}$ & III & $\begin{array}{l}\text { Heterozygous c.5989_5992del, } \\
\text { p.(Leu1997fs) }\end{array}$ & $\begin{array}{l}\text { Carrier status autosomal recessive } \\
\text { disease; no known dominant phenotype }\end{array}$ \\
\hline 25 & TMEM67 & Pathogenic & $\mathrm{F}$ & II & $\begin{array}{l}\text { Heterozygous c.958A>T, } \\
\text { p.(Ser320Cys) }\end{array}$ & $\begin{array}{l}\text { Carrier status autosomal recessive } \\
\text { disease; probably no or low-risk factor } \\
\text { for obesity }\end{array}$ \\
\hline 26 & TMEM67 & Pathogenic & $\mathrm{M}$ & II & $\begin{array}{l}\text { Heterozygous c. } 622 \mathrm{~A}>\mathrm{T} \text {, } \\
\text { p.(Arg208*) }\end{array}$ & $\begin{array}{l}\text { Carrier status autosomal recessive } \\
\text { disease; probably no or low-risk factor } \\
\text { for obesity }\end{array}$ \\
\hline 27 & WDPCP & Pathogenic & $\mathrm{F}$ & II & $\begin{array}{l}\text { Heterozygous c.160G }>\text { A, } \\
\text { p.(Asp54Asn) }\end{array}$ & $\begin{array}{l}\text { Carrier status autosomal recessive } \\
\text { disease; probably no or low-risk factor } \\
\text { for obesity }\end{array}$ \\
\hline
\end{tabular}


Table 5 (continued)

\begin{tabular}{llllll}
\hline No. Gene & $\begin{array}{l}\text { Genetic } \\
\text { defect }\end{array}$ & Sex & Class $^{\mathrm{a}}$ & Variation & Explanation \\
\hline \multicolumn{4}{l}{ Mutations in comorbidity risk genes } \\
\hline 28 & IRS1 & VUS & F & I & $\begin{array}{l}\text { Heterozygous c.1835A }>\mathrm{G}, \\
\text { p.(Tyr612Cys) }\end{array}$ \\
\hline 29 & IRS2 & VUS & F & II & $\begin{array}{l}\text { Heterozygous c.319G }>\mathrm{T}, \\
\text { p.(Ala107Ser) }\end{array}$ \\
\hline
\end{tabular}

VUS, variant of unknown clinical significance. ${ }^{\text {a }}$ According to the WHO classification [24], i.e., class I, BMI between 30.00 and 34.99; class II, BMI between 35.00 and 39.99; and class III, BMI equal to or greater than 40.00 .

The mean birth weight was 3,402 $\pm 744 \mathrm{~g}$ in the overall group (Table 3 ). The prevalence of a high birth weight was $19.5 \%$. No significant between-group difference or trend was found among the obesity classes.

The average amount of sleep in the total obese group was $7.1 \pm 1.4 \mathrm{~h} / \mathrm{night}$, which was consistent across classes. Sleep deprivation, defined as a sleep duration of less than $6 \mathrm{~h}$, was reported in $14.5 \%$ of the outpatients (Table 3). The diagnosis of OSAS was confirmed in 45 outpatients $(11.0 \%)$ prior to the clinic visit. After examinations for suspected OSAS, there were in total 56 outpatients $(13.7 \%)$ with confirmed OSAS, excluding those who declined further assessments or decided to be investigated elsewhere (Fig. 2b). With regard to the obesity classes, there was a significant positive trend between OSAS and obesity class (4.4, 15.3 , and $15.9 \%$ in the consecutive classes, respectively; $p=0.027$, adjusted for sex and age).

\section{Self-Reported Causes of Marked Weight Gain}

A total of 224 (54.9\%) outpatients reported having experienced at least one moment of marked weight gain. The most common reported trigger was the use of medical drugs, which occurred in 69 out of 408 (16.9\%) subjects in the total study population. Among these patients, weight gain was most frequently preceded by use of corticosteroids (33.3\%), followed by use of antidepressants and/or antipsychotics (24.6\%), hormonal contraceptives (23.2\%), and other drugs (18.8\%). A health-related cause (e.g., thyroid disorder, menopause, and joint disorder) was the second most reported precipitating factor $(52 / 408 ; 12.8 \%)$ for marked weight gain. Other reported main causes were psychosocial stress (30/408; 7.4\%; e.g., relationship difficulties or divorce, death of a relative, and overall increased perceived stress), pregnancy-related causes $(29 / 408 ; 7.1 \%)$, substance cessation $(15 / 408 ; 3.7 \%$; stopped smoking or taking illicit drugs), and work-related factors (14/408; 3.4\%; e.g., change to a sedentary work style, shift work, retirement or cessation of work for other reasons). Sixteen patients $(3.9 \%)$ reported other reasons such as sleep deprivation, moving out of the parental home, or in vitro fertilization treatment, while 34 outpatients $(8.3 \%)$ were unaware of a potential cause. A moment of marked weight gain was most frequently reported in patients with class II obesity (63.9\%), which was significantly higher than in those with class III obesity $(48.2 \% ; p=0.003$, adjusted for sex and age) but not compared to class I obesity (55.1\%).

\section{Genetic Analysis}

A definitive genetic diagnosis could be made in 3 female patients (1.9\%) with class III obesity and this was based on known pathogenic mutations in the MC4R $(n=2)$ and POMC $(n=1)$ genes (Table 5). Likely pathogenic contributing genetic variants were identified in 
Savas et al.: Potential Weight-Inducing Factors in Obesity

9 patients (5.6\%), and another 15 patients (9.3\%) were shown to be carriers of mutations associated with autosomal recessive diseases probably conferring no or only a low increased risk for obesity. Two patients were identified as having a mutation in one of the screened comorbidity genes (i.e., IRS1 $[n=1]$ and IRS2 [ $n=1]$ ). Mutations were found to be more present in the higher obesity classes; however, inferential analysis for differences between classes was not performed due to low numbers.

\section{Discussion}

In the present study, we extensively phenotyped subjects with obesity for various factors potentially contributing to obesity, including genetic predispositions, and assessed selfreported causes of marked weight gain. Interestingly, we found that about half of the obese subjects were using one or more prescribed drugs associated with weight gain. The use of corticosteroids was particularly high in our sample, which was especially remarkable since drug use, in general, was reported as the most common triggering factor for marked weight increase. In this light, it is interesting to mention that we recently found strong associations between local corticosteroids (e.g., inhaled or nasal) and an increased BMI in a large population-based study [25].

Obesity is frequently associated with the onset or exacerbation of different comorbidities which often require a pharmacological intervention, such as hypertension, type 2 diabetes mellitus, gastroesophageal reflux disease, asthma, and depression. Unfortunately, some of these drugs may induce weight gain or complicate the process of weight loss. Interestingly, drug use was the most self-reported triggering factor for marked weight gain in our study population. Highest user rates were mainly found for corticosteroids, and we previously reported evident differences in recent use of these between obese and nonobese subjects [26]. It was notable that, besides corticosteroids and psychotropic drugs, also hormonal contraceptives were frequently suggested as a trigger for marked weight gain in women. However, a Cochrane review by Gallo et al. [22] could not establish a causal relationship between the popular combination contraceptives and weight gain. Unfortunately, the type of hormonal contraceptive used during periods of marked weight gain in our female users was largely unknown.

First-line assessment of obesity generally includes investigation of the more generally known weight-inducing disorders which are mainly of hormonal origin. This could explain why we only found few new cases of hypothyroidism and PCOS and none for Cushing's syndrome and growth hormone deficiency. With regard to the thyroid functioning, the prevalence rate of hypothyroidism was much higher compared to the rate in the general population $[27,28]$. This may have attributed to weight gain over time and could perhaps still be a contributing factor in $10 \%$ of our hypothyroid patients who are (biochemically) undertreated [29]. Moreover, we found a high prevalence of PCOS as compared to previous findings in unselected populations $[30,31]$. In men, we found a high percentage of new hypogonadism cases. The reverse causality between hypogonadism and obesity in men in combination with the lack of data on clinically related signs and symptoms complicates the contributing role of low testosterone with regard to obesity in our male outpatients. Nevertheless, testosterone suppletion in obese hypogonadal men seems to be effective with regard to sustained weight loss in the long term [32] while, importantly, weight loss by itself can also increase testosterone levels [33].

With regard to menarche, we found a relatively younger median age of onset in comparison to the general Dutch female population (12.0 vs. 13.1 years) [34]; however, the reason for this difference is not necessarily clear. The direct link between age at menarche and adulthood obesity seems less evident and both are considered to be subsequent to a high childhood BMI 
Savas et al.: Potential Weight-Inducing Factors in Obesity

and/or increased sexual maturation due to other factors [3], while a low socioeconomic status has also been suggested to give rise to both menarche at a young age and obesity in adult life [35].

A high weight at birth, which appears to have a differentiating capacity with regard to weight and BMI in adulthood, was 2 -fold more common in our cohort when compared to the general population $[36,37]$. Various studies have shown that adults but also children with a high birth weight have more adverse anthropometric and body compositional features in comparison to normal birth weight subjects, whereas no differences have been found for subjects with a low birth weight $[5,37]$. Similar findings were also found in a comprehensive meta-analysis which showed a positive association between a high birth weight and adult obesity [4].

We found a relatively higher percentage of subjects with a self-reported sleep duration of less than $6 \mathrm{~h} / \mathrm{night}$ when compared to numbers from the general population $[8,38]$. In spite of differences in sleep requirement, such a short sleep duration is in general associated with a higher body weight and obesity [39]. In addition to the longer time awake increasing the opportunity for food consumption, it has been found that sleep deprivation can lead to derangement of appetite-regulating hormones (e.g., leptin, ghrelin, and cortisol) which can result in a greater appetite and a more energy-dense food intake $[9,40]$. The interplay between sleep deprivation, OSAS, and obesity [41] further supports the importance of sufficient sleep for a healthy body weight.

Genetic analysis is relatively new in the diagnostic workup of nonsyndromic obesity. We here identified a definite genetic cause for the obesity phenotype in 3 patients. The identified underlying molecular defects (MC4R and POMC mutations) could offer (future) personalized treatment programs for these patients $[42,43]$. One could also hypothesize that certain mutations could possibly indicate a contraindication for certain obesity treatment options in cases with a negative response to treatment. For patients themselves, it is often a psychological burden to be blamed by society for not being able to lose weight. In our clinical experience, a genetic diagnosis could perhaps aid in understanding and accepting why they show a different treatment response when compared to others and thereby increase the social support and decrease stigmatization. Our results, however, showed that the majority of the patients who received an abnormal result were carriers of a variant of unknown significance that could possibly contribute to the obesity phenotype. An individual combination of different variants of unknown significance (polygenic inheritance), each having a small effect on weight gain, might well add up to a larger obesity risk for such a person. Besides, most of these comprised the $B B S$ gene mutations for which heterozygosity has been postulated as a risk factor in obesity [44]. Frequency analysis in an obesity cohort and segregation analysis in family members showed, however, that $B B S$ carriage is probably not an important risk factor for obesity [45]. Future studies are needed to assess the clinical significance and confirm a possible association between obesity and the uncertain variants we identified here.

In the current study, we comprehensively and systematically evaluated various medical conditions as well as lifestyle, iatrogenic, and genetic factors related to weight gain in a single study population of subjects with obesity. Despite the distribution of the patients over all obesity classes, it is conceivable that our patients are more prone to underlying disorders in comparison to the general obese population given the setting of our clinic as an obesity expertise center. Unfortunately we did not have a control cohort and hence used literature based on general population data for comparison. Additionally, some of the data are selfreported and could hence be subject to recall bias. Furthermore, it should be emphasized that the number of genetic variations found may be underestimated since it does not include other genetic (syndromic) causes, chromosomal abnormalities (e.g., Turner syndrome), genomic microdeletions and duplications (e.g., 16p11.2 deletion syndrome), methylation abnormal- 
ities (e.g., Prader-Willi syndrome), uniparental disomy (e.g., UPD14), or triplet repeat expansions (e.g., fragile X syndrome) associated with obesity, as these are not detectable by the applied method. However, during our clinical assessment and physical examination we observed no signs or symptoms of these syndromes in this group of patients with obesity.

\section{Conclusion}

In conclusion, a thorough evaluation of potential weight-inducing factors in subjects with obesity showed especially a high prevalence of use of weight-inducing drugs and hormonal abnormalities, with virtually no differences across the distinct degrees of obesity. Drug use was additionally reported to be the most frequent trigger for marked weight gain, with corticosteroids being the most prevalent culprit. Although we could only confirm a definite genetic obesity diagnosis in $2 \%$ of the patients who were offered a genetic test, a personalized treatment option can (perhaps) be offered in a future clinical trial setting. This exemplifies the importance of genetic analysis in the diagnostic workup of obesity in specific patient groups (e.g., patients with symptoms suggesting monogenetic or syndromal obesity). Future large prospective cohort studies should focus on the factors as assessed here but also on others that could contribute to adiposity or impede weight loss (e.g., brown fat activity, endocrine disruptors, ambient temperature, and maternal age $[2,46])$. This in order to better understand the bidirectional relationship between most of the obesogenic factors and adiposity and to eventually decrease the social stigma surrounding obesity and optimize and develop more efficient and tailored weight loss interventions.

\section{Statement of Ethics}

Ethical approval for the current study was obtained from the local institutional review board. Informed consent was not required for the current work since we only assessed electronical medical records on an anonymized basis and did not perform any interventions or procedures.

\section{Disclosure Statement}

The authors have no conflict of interests to declare.

\section{Funding Source}

E.F.C.v.R. was funded by a Vidi grant from The Netherlands Organisation for Scientific Research NWO (grant No. 91716453).

\section{Author Contributions}

E.F.C.v.R. obtained funding. M.S., V.L.W., L.K., M.M.v.H., and E.F.C.v.R. contributed to the study design and acquisition of the data. M.S. and E.F.C.v.R. analyzed the data. M.S. drafted this paper. All of the authors contributed to data interpretation and provided critical revisions of this article. 
Savas et al.: Potential Weight-Inducing Factors in Obesity

\section{References}

1 Collaboration NC; NCD Risk Factor Collaboration (NCD-RisC). Trends in adult body-mass index in 200 countries from 1975 to 2014: a pooled analysis of 1698 population-based measurement studies with $19 \cdot 2$ million participants. Lancet. 2016 Apr;387(10026):1377-96.

2 Keith SW, Redden DT, Katzmarzyk PT, Boggiano MM, Hanlon EC, Benca RM, et al. Putative contributors to the secular increase in obesity: exploring the roads less traveled. Int J Obes. 2006 Nov;30(11):1585-94.

3 Pierce MB, Leon DA. Age at menarche and adult BMI in the Aberdeen children of the 1950s cohort study. Am J Clin Nutr. 2005 Oct;82(4):733-9.

4 Yu ZB, Han SP, Zhu GZ, Zhu C, Wang XJ, Cao XG, et al. Birth weight and subsequent risk of obesity: a systematic review and meta-analysis. Obes Rev. 2011 Jul;12(7):525-42.

5 Rillamas-Sun E, Sowers MR, Harlow SD, Randolph JF Jr. The relationship of birth weight with longitudinal changes in body composition in adult women. Obesity (Silver Spring). 2012 Feb;20(2):463-5.

6 Weaver JU. Classical endocrine diseases causing obesity. Front Horm Res. 2008;36:212-28.

7 Sheehan AH. Weight gain. In: Tisdale JE, Miller DA, editors. Drug-induced Diseases: Prevention, Detection, and Management. 2nd ed. Bethesda, MD, USA: American Society of Health-System Pharmacists; 2010. pp. 629-42.

8 Kohatsu ND, Tsai R, Young T, Vangilder R, Burmeister LF, Stromquist AM, et al. Sleep duration and body mass index in a rural population. Arch Intern Med. 2006 Sep;166(16):1701-5.

9 Taheri S, Lin L, Austin D, Young T, Mignot E. Short sleep duration is associated with reduced leptin, elevated ghrelin, and increased body mass index. PLoS Med. 2004 Dec;1(3):e62.

10 Tsai EC, Boyko EJ, Leonetti DL, Fujimoto WY. Low serum testosterone level as a predictor of increased visceral fat in Japanese-American men. Int J Obes Relat Metab Disord. 2000 Apr;24(4):485-91.

11 Gambineri A, Pelusi C, Vicennati V, Pagotto U, Pasquali R. Obesity and the polycystic ovary syndrome. Int J Obes Relat Metab Disord. 2002 Jul;26(7):883-96.

12 Romero-Corral A, Caples SM, Lopez-Jimenez F, Somers VK. Interactions between obesity and obstructive sleep apnea: implications for treatment. Chest. 2010 Mar;137(3):711-9.

13 Alders M. Classification of the population with a foreign background in The Netherlands: Statistic Netherlands, paper for the conference „The measure and mismeasure of populations. The statistical use of ethnic and racial categories in multicultural societies". Paris: CERI; 2001.

14 Apovian CM, Aronne LJ, Bessesen DH, McDonnell ME, Murad MH, Pagotto U, et al.; Endocrine Society. Pharmacological management of obesity: an endocrine Society clinical practice guideline. J Clin Endocrinol Metab. 2015 Feb;100(2):342-62.

15 Bray GA, Ryan DH. Medical therapy for the patient with obesity. Circulation. 2012 Apr;125(13):1695-703.

16 Malone M. Medications associated with weight gain. Ann Pharmacother. 2005 Dec;39(12):2046-55.

17 Cheskin LJ, Bartlett SJ, Zayas R, Twilley CH, Allison DB, Contoreggi C. Prescription medications: a modifiable contributor to obesity. South Med J. 1999 Sep;92(9):898-904.

18 Leslie WS, Hankey CR, Lean ME. Weight gain as an adverse effect of some commonly prescribed drugs: a systematic review. QJM. 2007 Jul;100(7):395-404.

19 Breum L, Fernstrom MH. Drug-induced obesity; International textbook of obesity. Hoboken: Wiley; 2002. p. 269-81.

20 Yoshikawa I, Nagato M, Yamasaki M, Kume K, Otsuki M. Long-term treatment with proton pump inhibitor is associated with undesired weight gain. World J Gastroenterol. 2009 Oct;15(38):4794-8.

21 Ratliff JC, Barber JA, Palmese LB, Reutenauer EL, Tek C. Association of prescription H1 antihistamine use with obesity: results from the National Health and Nutrition Examination Survey. Obesity (Silver Spring). 2010 Dec; 18(12):2398-400.

22 Gallo MF, Lopez LM, Grimes DA, Carayon F, Schulz KF, Helmerhorst FM. Combination contraceptives: effects on weight. Cochrane Database Syst Rev. 2014 Jan;(1):CD003987.

23 de Ronde W, van der Schouw YT, Pierik FH, Pols HA, Muller M, Grobbee DE, et al. Serum levels of sex hormonebinding globulin (SHBG) are not associated with lower levels of non-SHBG-bound testosterone in male newborns and healthy adult men. Clin Endocrinol (Oxf). 2005 Apr;62(4):498-503.

24 Obesity: preventing and managing the global epidemic. Report of a WHO consultation. World Health Organ Tech Rep Ser. 2000;894:i-xii.

25 Savas M, Muka T, Wester VL, van den Akker EL, Visser JA, Braunstahl GJ, et al. Associations between systemic and local corticosteroid use with metabolic syndrome and body mass index. J Clin Endocrinol Metab. 2017 Oct; 102(10):3765-74.

26 Savas M, Wester VL, Staufenbiel SM, Koper JW, van den Akker EL, Visser JA, et al. Systematic evaluation of corticosteroid use in obese and non-obese individuals: A multi-cohort study. Int J Med Sci. 2017 Jun;14(7):615-21.

27 Garmendia Madariaga A, Santos Palacios S, Guillén-Grima F, Galofré JC. The incidence and prevalence of thyroid dysfunction in Europe: a meta-analysis. J Clin Endocrinol Metab. 2014 Mar;99(3):923-31.

28 Hollowell JG, Staehling NW, Flanders WD, Hannon WH, Gunter EW, Spencer CA, et al. Serum tsh, t(4), and thyroid antibodies in the united states population (1988 to 1994): national health and nutrition examination survey (nhanes iii). J Clin Endocrinol Metab. 2002 Feb;87(2):489-99.

29 Fox CS, Pencina MJ, D’Agostino RB, Murabito JM, Seely EW, Pearce EN, et al. Relations of thyroid function to body weight: cross-sectional and longitudinal observations in a community-based sample. Arch Intern Med. 2008 Mar;168(6):587-92. 
Savas et al.: Potential Weight-Inducing Factors in Obesity

30 Asunción M, Calvo RM, San Millán JL, Sancho J, Avila S, Escobar-Morreale HF. A prospective study of the prevalence of the polycystic ovary syndrome in unselected Caucasian women from Spain. J Clin Endocrinol Metab. $2000 \mathrm{Jul} ; 85(7): 2434-8$.

31 Azziz R, Woods KS, Reyna R, Key TJ, Knochenhauer ES, Yildiz BO. The prevalence and features of the polycystic ovary syndrome in an unselected population. J Clin Endocrinol Metab. 2004 Jun;89(6):2745-9.

32 Saad F, Yassin A, Doros G, Haider A. Effects of long-term treatment with testosterone on weight and waist size in 411 hypogonadal men with obesity classes I-III: observational data from two registry studies. Int J Obes. 2016 Jan;40(1):162-70.

33 Corona G, Rastrelli G, Monami M, Saad F, Luconi M, Lucchese M, et al. Body weight loss reverts obesity-associated hypogonadotropic hypogonadism: a systematic review and meta-analysis. Eur J Endocrinol. 2013 May; 168(6):829-43.

34 Talma H, Schönbeck Y, van Dommelen P, Bakker B, van Buuren S, Hirasing RA. Trends in menarcheal age between 1955 and 2009 in the Netherlands. PLoS One. 2013 Apr;8(4):e60056.

35 Stöckl D, Döring A, Peters A, Thorand B, Heier M, Huth C, et al. Age at menarche is associated with prediabetes and diabetes in women (aged 32-81 years) from the general population: the KORA F4 Study. Diabetologia. 2012 Mar;55(3):681-8.

36 Apfelbacher CJ, Loerbroks A, Cairns J, Behrendt H, Ring J, Krämer U. Predictors of overweight and obesity in five to seven-year-old children in Germany: results from cross-sectional studies. BMC Public Health. 2008 May;8(1):171.

37 Hirschler V, Bugna J, Roque M, Gilligan T, Gonzalez C. Does low birth weight predict obesity/overweight and metabolic syndrome in elementary school children? Arch Med Res. 2008 Nov;39(8):796-802.

38 Krueger PM, Friedman EM. Sleep duration in the United States: a cross-sectional population-based study. Am J Epidemiol. 2009 May;169(9):1052-63.

39 Chaput JP, Després JP, Bouchard C, Tremblay A. The association between sleep duration and weight gain in adults: a 6-year prospective study from the Quebec Family Study. Sleep. 2008 Apr;31(4):517-23.

40 Spiegel K, Leproult R, Van Cauter E. Impact of sleep debt on metabolic and endocrine function. Lancet. 1999 Oct;354(9188):1435-9.

41 Beccuti G, Pannain S. Sleep and obesity. Curr Opin Clin Nutr Metab Care. 2011 Jul;14(4):402-12.

42 Kühnen P, Clément K, Wiegand S, Blankenstein O, Gottesdiener K, Martini LL, et al. Proopiomelanocortin deficiency treated with a melanocortin-4 receptor agonist. N Engl J Med. 2016 Jul;375(3):240-6.

43 Danielsson P, Janson A, Norgren S, Marcus C. Impact sibutramine therapy in children with hypothalamic obesity or obesity with aggravating syndromes. J Clin Endocrinol Metab. 2007 Nov;92(11):4101-6.

44 Croft JB, Swift M. Obesity, hypertension, and renal disease in relatives of Bardet-Biedl syndrome sibs. Am J Med Genet. 1990 May;36(1):37-42.

45 Kleinendorst L, Massink MP, Cooiman MI, Savas M, van der Baan-Slootweg OH, Roelants RJ, et al. Genetic obesity: next-generation sequencing results of 1230 patients with obesity. J Med Genet. 2018 Sep;55(9):57886.

46 Harms M, Seale P. Brown and beige fat: development, function and therapeutic potential. Nat Med. 2013 Oct; 19(10):1252-63. 